\title{
Excitatory Effects of Orexin-A on Nucleus Tractus Solitarius Neurons Are Mediated by Phospholipase $\mathrm{C}$ and Protein Kinase C
}

\author{
Bo Yang, ${ }^{1}$ Willis K. Samson, ${ }^{2}$ and Alastair V. Ferguson ${ }^{1}$ \\ ${ }^{1}$ Department of Physiology, Queen's University, Kingston, Ontario, Canada K7L 3N6, and ${ }^{2}$ Pharmacological and Physiological Science, St. Louis University \\ School of Medicine, St. Louis, Missouri 63104
}

Orexin (ORX)-A is a 33-amino acid peptide with demonstrated roles in the regulation of energy metabolism, autonomic control, and sleep. Orexin receptors (OXRs), $\mathrm{OX}_{1} \mathrm{R}$ and $\mathrm{OX}_{2} \mathrm{R}$, and immunoreactive axons are present in the nucleus tractus solitarius (NTS). We demonstrated previously that bath application of ORX-A depolarizes NTS neurons through activation of a nonselective cationic conductance (NSCC) and inhibition of a sustained potassium current $\left(I_{\mathrm{K}}\right)$. The present study examined the signaling pathways underlying the excitatory effects of ORX-A on NTS neurons using whole-cell patch-clamp recording techniques. Inclusion of guanosine $5^{\prime}$-0-(2thiodiphosphate) in the internal pipette solution abolished the effects of ORX-A, confirming that the actions of ORX-A are mediated by G-protein-coupled receptors. The responses of ORX-A were also blocked by a phospholipase C (PLC) inhibitor, D609, and by a nonselective protein kinase (PK) inhibitor, $\mathrm{H7}$, demonstrating the involvement of PLC and protein kinases. However, PKA appears not to play a role, because the depolarizing effects of ORX-A were still observed when the PKA inhibitor peptide (6-22) was included in the pipette solution, and bath application of 8-bromo-cAMP (a PKA agonist) was without effect on NTS neurons. In contrast, 12-0tetradecanoylphorbol-13-acetate (a PKC agonist) depolarized NTS neurons, and bisindolylmaleimide (BIS), a PKC inhibitor, abolished the depolarizing effects of ORX-A. Finally, voltage-clamp experiments demonstrated that BIS also blocked the activation of NSCC and inhibition of $I_{\mathrm{K}}$ by ORX-A in NTS neurons. These results therefore show that the excitatory effects of ORX-A on NTS neurons are mediated through activation of the PLC-PKC-NSCC and $-I_{\mathrm{K}}$ signaling pathways, which probably result from OXR-coupled activation of $\mathrm{G}_{\mathrm{q}}$.

Key words: nucleus tractus solitarius; orexin-A; patch clamp; nonselective cationic conductance; $I_{\mathrm{K}}$; electrophysiology; phospholipase C; protein kinase $\mathrm{C}$; central control of cardiovascular function

\author{
Introduction \\ Orexins (ORXs)-hypocretins are two neuropeptides that were \\ discovered in 1998 (de Lecea et al., 1998; Sakurai et al., 1998). In \\ contrast to the exclusive localization of ORX-producing neurons \\ in the hypothalamus (de Lecea et al., 1998), orexinergic fibers \\ project widely throughout the CNS (Peyron et al., 1998; Date et \\ al., 1999). The widespread central distribution of ORX peptides, \\ receptors, and axons indicate that orexinergic neurons link the \\ hypothalamus to many other central autonomic control centers \\ and play important roles in integrating the complex physiology \\ underlying feeding behavior and other autonomic functions. \\ The biological actions of orexins are transduced via two \\ ORX receptors (OXRs) belonging to the seven-transmembrane \\ G-protein-coupled receptor (GPCR) superfamily (Sakurai et al., \\ 1998). $\mathrm{OX}_{2} \mathrm{R}$ is nonselective, whereas $\mathrm{OX}_{1} \mathrm{R}$ is substantially more \\ sensitive to ORX-A (Sakurai et al., 1998). The expression pattern \\ of OXR mRNA (Sakurai et al., 1998; Trivedi et al., 1998; Lu et al.,

\footnotetext{
Received March 7, 2003; revised May 16, 2003; accepted May 16, 2003.

This work was supported by a grant to A.V.F. and W.K.S. from the National Institutes of Health. We thank Dr. N. S. Magoski for helpful advice.

Correspondence should be addressed to Dr. Alastair V. Ferguson, Department of Physiology, Queen's University, Kingston, Ontario, Canada K7L 3N6. E-mail: avf@post.queensu.ca.
} \\ Copyright $\odot 2003$ Society for Neuroscience $\quad 0270-6474 / 03 / 236215-08 \$ 15.00 / 0$
}

2000; Marcus et al., 2001) and protein (Hervieu et al., 2001; Cluderay et al., 2002), although extensive, is not homogeneous in different subregions of the CNS. $\mathrm{OX}_{2} \mathrm{R}$ couples to a $\mathrm{G}_{\mathrm{q}}$-protein (Sakurai et al., 1998), the activation of which stimulates phospholipase C (PLC) (Exton, 1994). Orexins have also been shown to increase intracellular $\mathrm{Ca}^{2+}\left(\left[\mathrm{Ca}^{2+}\right]_{\mathrm{i}}\right)$ in hypothalamic and cortical neurons as a result of extracellular $\mathrm{Ca}^{2+}$ influx (Van Den Pol et al., 1998, 2001). This $\left[\mathrm{Ca}^{2+}\right]_{\mathrm{i}}$ elevation is blocked by bisindoylmaleimide (BIS), a PKC inhibitor. These data suggest that OXRs activate protein kinase $(\mathrm{PK}) \mathrm{C}$, which in turn phosphorylates and thereby activates voltage-gated $\mathrm{Ca}^{2+}$ channels (Van Den Pol et al., 1998). Subsequently, Uramura et al. (2001) reported similar responses in isolated rat ventral tegmental neurons, in which ORX-A increased $\left[\mathrm{Ca}^{2+}\right]_{\mathrm{i}}$ through activation of nitrendipineand $\omega$-conotoxin-sensitive $\mathrm{Ca}^{2+}$ channels, a response that is sensitive to a PKC inhibitor (calphostin C) and a phosphatidylcholine-specific PLC inhibitor (D609). Similar $\left[\mathrm{Ca}^{2+}\right]_{\mathrm{i}}$ elevation has also been documented in neurons from rat embryonic spinal cord (Van Den Pol, 1999), locus ceruleus, and tuberomamillary nucleus (Horvath et al., 1999; Eriksson et al., 2001).

The nucleus tractus solitarius (NTS), located in the medulla, plays essential roles in the integration of cardiovascular, respiratory, gustatory, hepatic, and renal control mechanisms (Law- 
rence and Jarrott, 1996). This nucleus receives afferent input from and sends efferent output to many essential autonomic control centers in the hypothalamus, midbrain, and spinal cord (Yates et al., 1994). ORX-immunoreactive (IR) axons and OXRs are present in NTS, and intracerebroventricular ORX-A induces fos activation of NTS neurons (Date et al., 1999). We reported recently that ORX-A acts in NTS to cause rapid, reversible, sitespecific increases in blood pressure and heart rate (Smith et al., 2002), and that bath application of ORX-A directly depolarizes NTS neurons through the activation of a nonselective cationic conductance (NSCC) and inhibition of a sustained potassium current $\left(I_{\mathrm{K}}\right)$ (Yang and Ferguson, 2003). The present study aimed to investigate the signaling mechanisms mediating the effects of ORX-A on NTS neurons by combining neuropharmacological tools with whole-cell patch-clamp techniques.

\section{Materials and Methods}

Medullary slice preparation. Male Sprague Dawley rats (125-225 gm; Charles River, St. Constant, Quebec, Canada) were decapitated, and the brainstem was quickly removed from the skull and immersed in cold $\left(0-2^{\circ} \mathrm{C}\right)$ artificial CSF (aCSF). Medullary slices (400 $\mu \mathrm{m}$ thick), including NTS, were cut using a vibratome (VT1000S; Leica, Nussloch, Germany) and incubated in oxygenated aCSF $\left(95 \% \mathrm{O}_{2}-5 \% \mathrm{CO}_{2}\right)$ for at least $90 \mathrm{~min}$ at room temperature. Before recording, slices were transferred into an interface-type recording chamber and continuously perfused with oxygenated aCSF through a gravity perfusion system. The aCSF flow rate was adjusted to $\sim 1.5 \mathrm{ml} / \mathrm{min}$ and maintained constant throughout the entire recording period. All of the experiments were performed at room temperature $\left(21-22^{\circ} \mathrm{C}\right)$. All of the procedures conformed to the standards outlined by the Canadian Council on Animal Care, and protocols were approved by the Queen's University Animal Care Committee.

Electrophysiological methods. Whole-cell patch recordings were obtained using the whole-cell configuration of the blind gigaseal patchclamp technique (Li and Ferguson, 1996; Yang and Ferguson, 2003) to record from NTS neurons, most of which are located in the commissural region of the nucleus. Electrodes of 4-7 $\mathrm{M} \Omega$ resistance were pulled from TW150F-6 glass micropipettes (World Precision Instruments, Sarasota, FL) on a horizontal Flaming-Brown micropipette puller (model P-87 or P-97; Sutter Instrument, Novato, CA) and were filled with the appropriate filling solution (see Experimental solutions). After establishment of a $>1 \mathrm{G} \Omega$ seal, a brief suction pulse was applied to rupture the membrane and achieve the whole-cell configuration. Signals were amplified and processed using an AxoClamp 2B (Axon Instruments, Foster City, CA) amplifier. Series resistance $(<15 \mathrm{M} \Omega)$ was not compensated. An Ag$\mathrm{AgCl}$ electrode connected to the bath solution via a $\mathrm{KCl}$-agar bridge served as reference. After recording from each NTS neuron, the pipette was withdrawn from the cell membrane, the remaining junction potential was measured $(3-7 \mathrm{mV})$, and the appropriate correction was applied to all of the data presented. Drugs were applied by switching perfusion from aCSF to a solution containing the desired drug. In addition, certain chemicals were added to the standard internal pipette solution. All of the signals were filtered at $3 \mathrm{kHz}$, digitized using the CED 1401 plus interface (Cambridge Electronic Design, Cambridge, UK) at $5 \mathrm{kHz}$, and stored on computer for off-line analysis. Data were collected using the Signal (episode-based capture) or Spike2 (continuous-recording) packages (Cambridge Electronic Design). Leak current was routinely subtracted using the option offered by the Signal program (Cambridge Electronic Design).

Cells were defined as neurons by the presence of at least $70 \mathrm{mV}$ action potentials (current-clamp recordings) or by the presence of large rapid voltage-activated inward currents that were blocked by TTX (voltageclamp recordings).

Experimental solutions. The standard internal pipette solution contained (in mM): $140 \mathrm{~K}$-gluconate, $0.1 \mathrm{CaCl}_{2}, 2 \mathrm{MgCl}_{2}, 1.1 \mathrm{EGTA}, 10$ HEPES, and $2 \mathrm{Na}_{2} \mathrm{ATP}$, and was adjusted to $\mathrm{pH} 7.25$ with $\mathrm{KOH}$. The control bath solution consisted of aCSF (in mM): $124 \mathrm{NaCl}, 2 \mathrm{KCl}, 1.25$
$\mathrm{KH}_{2} \mathrm{PO}_{4}, 2.0 \mathrm{CaCl}_{2}, 1.3 \mathrm{MgSO}_{4}, 20 \mathrm{NaHCO}_{3}$, and 10 glucose. Osmolarity was maintained between 285 and $300 \mathrm{mOsm}$, and $\mathrm{pH}$ was maintained between 7.3 and 7.4.

Peptides and drugs. ORX-A (Phoenix Pharmaceuticals, Belmont, CA) was prepared on the day of experiment by diluting $50 \mu \mathrm{l}$ aliquots of $10^{-5}$ $\mathrm{M}$ stock solution stored at $-70^{\circ} \mathrm{C}$ to $10^{-8} \mathrm{M}$ in aCSF. In voltage-clamp experiments in which $\mathrm{K}^{+}$channels were examined, TTX $(5 \mu \mathrm{M})$ was added to external solutions to block the $\mathrm{Na}^{+}$channels. 4-Aminopyridine (4-AP) ( $5 \mathrm{~mm}$ ) was applied in the aCSF to block the transient $\mathrm{K}^{+}$current. The role of GPCRs in the signaling process was examined by including in the internal solution $0.5 \mathrm{~mm}$ guanosine $5^{\prime}$-O-(2-thiodiphosphate) (GDP- $\beta$-S), a nonhydrolysable GDP analog that inhibits G-protein-mediated intracellular signaling (Ho et al., 1986). A phosphatidylcholine-specific PLC inhibitor, D609 (10 $\mu \mathrm{M})$, was used in aCSF to examine the involvement of PLC (Uramura et al., 2001). A nonselective protein kinase inhibitor, $\mathrm{H} 7(50 \mu \mathrm{M})$, was applied in the pipette solution to determine whether protein kinases play a role in mediating these actions of ORX-A (Quick et al., 1992). Internal pipette solutions containing PKA inhibitor peptide (6-22) (1 $\mu \mathrm{M})$ (Glass et al., 1989 ) and aCSF containing 8-bromo-cAMP (a PKA agonist) $(200 \mu \mathrm{M})$ (Hei et al., 1991) were also used to explore the roles of PKA. Similarly, aCSF containing BIS II ( $1 \mu \mathrm{M})$ (Toullec et al., 1991) and 12-Otetradecanoylphorbol-13-acetate (TPA) (a PKC agonist) (100 nM) (Rebois and Patel, 1985) and its negative control, 4- $\alpha$-phorbol 12-myristate 13 -acetate (4- $\alpha$-PMA) (100 nM) (Fischer et al., 1991), were used to examine whether PKC plays a role. All of these agonists, antagonists, and their controls were prepared on the day of experiment by diluting stock solutions stored at appropriate temperatures into aCSF or internal solution. The concentrations used in this study were in accordance with those shown to be effective in the literature cited above. All of the chemicals, unless otherwise stated, were obtained from Sigma (St. Louis, MO).

Definition of response. A series of hyperpolarizing current pulses were applied to determine the identity of each neuron as a DE (delayed excitation), PIR (postinhibitory rebound), or NON (neither DE nor PIR) cell on the basis of its electrophysiological fingerprint (Vincent and Tell, 1997). Neurons were required to maintain a stable baseline for at least 2 min before application of test agents. A response to ORX-A was arbitrarily defined as a sustained change in membrane potential of $>3 \mathrm{mV}$.

Statistical analysis. For statistical analysis of effects of ORX-A and TPA on NTS neurons under various conditions, means were calculated from cells that were determined to have been affected using the above criteria. Results were analyzed by using a $2 \times 2$ contingency table and the Fisher's exact test. Changes in steady-state $\mathrm{K}^{+}$conductances in response to ORX-A were compared using Student's $t$ test. A minimum $p$ value of $<0.05$ was selected to determine significance. All of the mean values are plotted as means \pm SEM.

\section{Results}

Whole-cell patch recordings were obtained from a total of 188 NTS neurons. All of these cells demonstrated action potentials with amplitude of $>70 \mathrm{mV}$ (arbitrary minimum cutoff for inclusion), and they had a mean resting membrane potential of $-55.4 \pm 0.2 \mathrm{mV}$ and a mean input resistance of $3.4 \pm 0.1 \mathrm{G} \Omega$. Similar proportions of DE, PIR, and NON cells were found to be responsive to ORX-A and manipulations of signaling pathways, and therefore, these cell types were grouped together for all of the subsequent analysis.

\section{The excitatory effects of ORX-A on NTS neurons are mediated by GPCRs}

In our previous study (Yang and Ferguson, 2003), current-clamp recordings showed that $\sim 90.7 \%$ NTS neurons (78 of 86 cells) were depolarized by bath perfusion of ORX-A, and similar proportions of DE, PIR, and NON cells were found to be responsive to ORX-A. In the first section of this study, the role of GPCRs in the signaling process was examined by including in the internal solution $0.5 \mathrm{~mm}$ GDP- $\beta$-S, a nonhydrolysable GDP analog that 
A

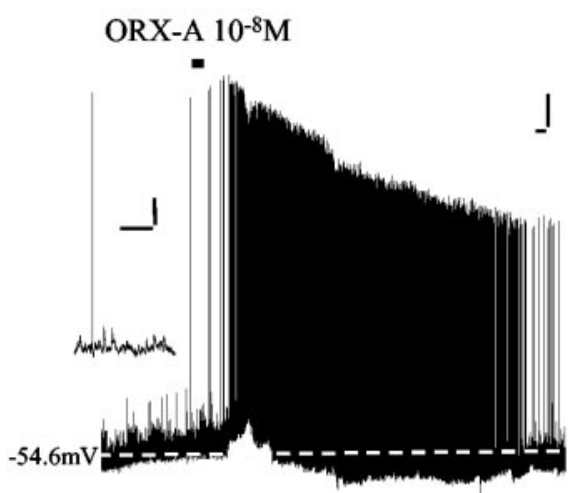

B

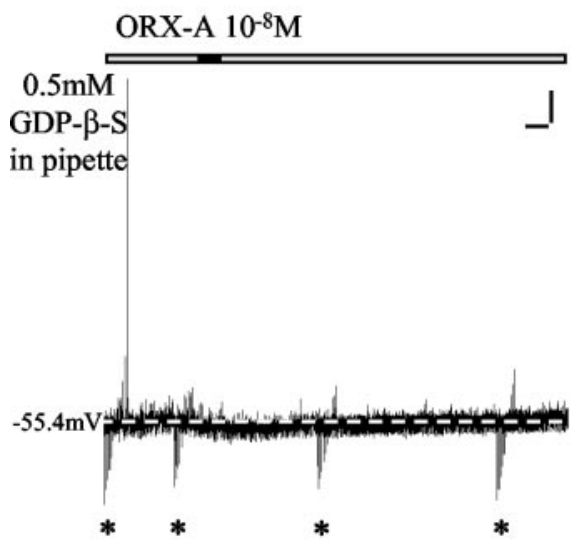

C

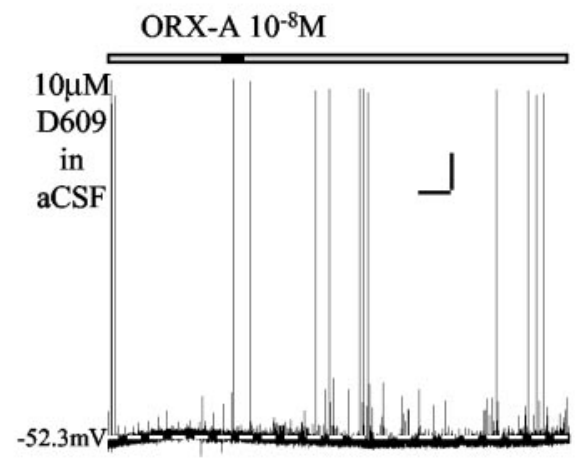

D

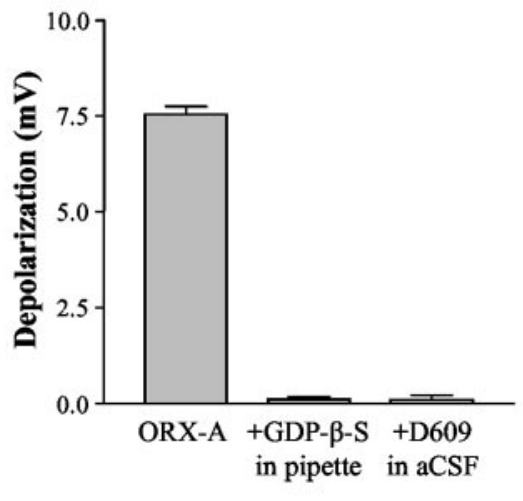

Figure 1. The excitatory effects of ORX-A on NTS neurons are mediated by GPCRs and PLC. A, Whole-cell current-clamp recording with standard internal solution from an NTS neuron shows that bath application of $10^{-8} \mathrm{M}$ ORX-A (represented in this and other figures by the horizontal bar above each trace) resulted in rapid sustained depolarization accompanied by a rapid increase in firing frequency of action potentials. After washout of ORX-A, the membrane potential and action potential frequency returned to control levels. Calibration: vertical, $10 \mathrm{mV}$; horizontal, $60 \mathrm{sec}$. The dashed line indicates baseline membrane potential. The inset shows expanded time scale from the same recording. This trace illustrates action potentials (truncated) and postsynaptic potentials (of up to $10 \mathrm{mV}$ ) with baseline noise of $<1 \mathrm{mV}$. Calibration: vertical, $10 \mathrm{mV}$; horizontal, $1 \mathrm{sec}$. $B$, Whole-cell currentclamp recording from an NTS neuron with $0.5 \mathrm{~mm} \mathrm{GDP-} \beta$-S in the internal pipette solution demonstrates that bath administration of $10^{-8} \mathrm{~m}$ ORX-A did not depolarize this cell. Calibration: vertical, $10 \mathrm{mV}$; horizontal, $60 \mathrm{sec}$. The dashed line indicates baseline membrane potential. The asterisks indicate the voltage responses to hyperpolarizing current pulses (to measure the input resistance). C, Whole-cell current-clamp recording from an NTS neuron with D609 $(10 \mu \mathrm{m})$ in aCSF reveals that bath administration of $10^{-8}$ м ORX-A did not depolarize this cell. Calibration: vertical, $10 \mathrm{mV}$; horizontal, $60 \mathrm{sec}$. The dashed line indicates baseline membrane potential. $D$, This bar graph summarizes the depolarization of NTS neurons caused by $10^{-8} \mathrm{M} 0 \mathrm{RX}-\mathrm{A}(7.6 \pm 0.2 \mathrm{mV}$; $n=5), 10^{-8} \mathrm{M}$ ORX-A recorded with $0.5 \mathrm{~mm}$ GDP- $\beta$-S in the pipette solution $(0.1 \pm 0.1 \mathrm{mV} ; n=12)$, and $10^{-8} \mathrm{M} 0 \mathrm{RX}-\mathrm{A}$ with $10 \mu \mathrm{m}$ D609 in aCSF (0.1 $\pm 0.1 \mathrm{mV} ; n=6)$. Error bars indicate SE.

inhibits G-protein-mediated intracellular effects. As illustrated in Figure $1 A$, NTS neurons normally depolarize in response to $10^{-8}$ M ORX-A, and these depolarizations are accompanied by a rapid increase in firing frequency of action potentials. After washout of ORX-A with control aCSF, both the membrane potential and action potential frequency returned to control levels. In contrast, inclusion of GDP- $\beta$-S in the pipette solution abolished the depolarizing effect of ORX-A $\left(10^{-8} \mathrm{M}\right)$, as shown in Figure $1 \mathrm{~B}$. None of the 12 cells tested with GDP- $\beta$-S in the pipette solution responded to bath application of ORX-A. In contrast, $10^{-8} \mathrm{M}$ ORX-A induced a $7.6 \pm 0.2 \mathrm{mV}(n=5)$ depolarization in 5 of 5 NTS neurons recorded with standard internal solution from the same medullary slices. The difference between these two groups is statistically significant (Fisher's exact test, $p=0.0002$ ). These data confirm the report (Sakurai et al., 1998) that the excitatory effects of ORX-A on NTS neurons are mediated by GPCRs.

PLC is involved in mediating the ORX-A actions on NTS neurons

Previous work has shown that the $\mathrm{OX}_{2} \mathrm{R}$ couples to a $\mathrm{G}_{\mathrm{q}}$ protein (Sakurai et al., 1998), the activation of which results in increases in PLC (Exton, 1994). In addition, ORX-A was subsequently demonstrated to increase $\left[\mathrm{Ca}^{2+}\right]_{\mathrm{i}}$ in isolated rat ventral tegmental neurons through activation of N-type and L-type voltage-gated $\mathrm{Ca}^{2+}$ channels, a response that is also sensitive to a PKC inhibitor and a phosphatidylcholine-specific PLC inhibitor (D609) (Uramura et al., 2001). We therefore examined the effects of the PLC inhibitor D609 $(10 \mu \mathrm{M})$ on the excitatory effects of ORX-A on NTS neurons. This inhibitor abolished the effects of ORX-A on NTS neurons $(n=6)$, as shown in the example in Figure $1 C$, with a mean depolarization in response to ORX-A in the presence of D609 of $0.1 \pm 0.1 \mathrm{mV}$ compared with the control values of $7.8 \pm 0.2 \mathrm{mV}(n=55)$ $(p<0.0001)$. These results indicate that the excitatory effects of ORX-A are mediated by a phosphatidylcholine-specific phospholipase C.

\section{Protein kinases mediate ORX-A actions on NTS neurons}

PKC has been suggested to mediate the actions of orexin on ovine somatotropes and nucleus pontis oralis neurons (Chen et al., 2002; Xi et al., 2002). We therefore examined effects of a nonselective PK inhibitor, H7 (50 $\mu \mathrm{M})$, on ORX-A-induced depolarization of NTS neurons. None of the 9 cells tested responded to bath administration of ORX-A, as illustrated in Figure 2 B. In contrast, 11 of 13 NTS neurons from the same slices recorded with pipette solution containing the vehicle for $\mathrm{H} 7$ (1:1000 ethanol) were depolarized by ORX-A with a mean amplitude of $7.9 \pm 0.1 \mathrm{mV}(n=11 / 13)$, as illustrated by an example in Figure $2 A$ and summary data in $C$. These data closely match the proportion $(90.7 \%)$ of NTS neurons depolarized by ORX-A and the mean amplitude of depolarization induced by $10^{-8} \mathrm{M}$ ORX-A $(7.8 \pm 0.2 \mathrm{mV} ; n=49)$ documented in our previous study (Yang and Ferguson, 2003). These results from the ethanol and H7 groups are statistically significant (Fisher's exact test, $p=$ $0.0001)$. It is therefore implied that protein kinases are involved in mediating the actions of ORX-A on NTS neurons.

\section{PKA inhibition does not influence the actions of ORX-A on NTS neurons}

Bath administration of $200 \mu \mathrm{M}$ 8-bromo-cAMP (a cell membrane-permeable, specific PKA agonist) did not depolarize NTS neurons ( $n=6$ of 6 ), as illustrated in Figure $3 A$. In addition, as demonstrated by the example in Figure $3 B$ and summary data in $C$, recordings with $1 \mu \mathrm{M}$ PKA inhibitor peptide (6-22) in internal solution revealed that bath application of ORX-A still 
A

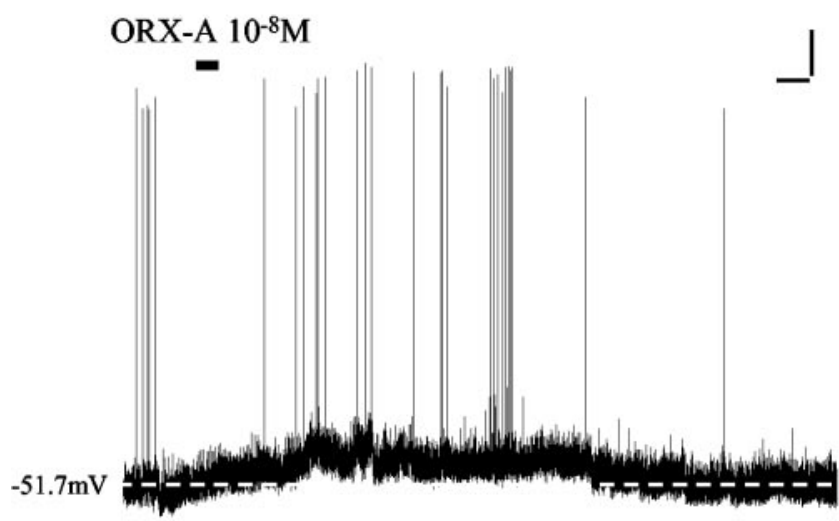

B

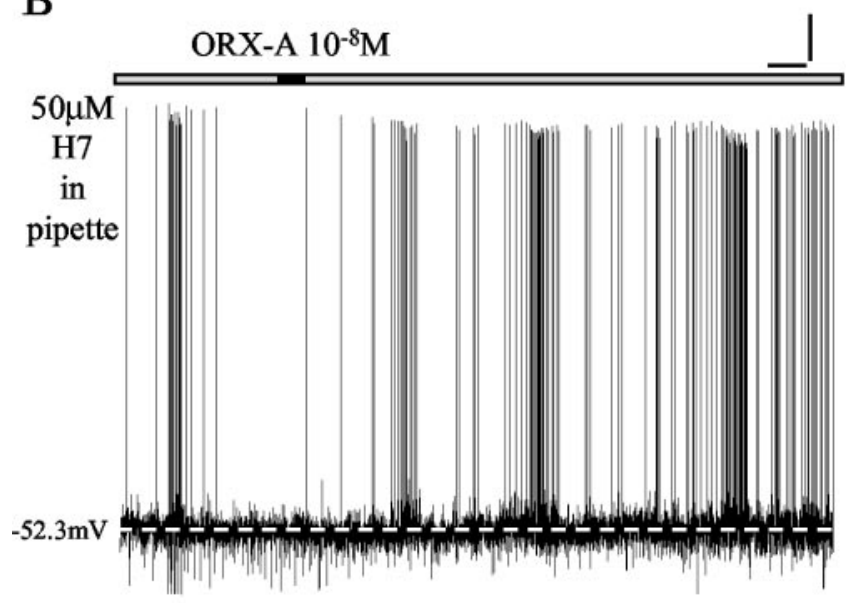

C

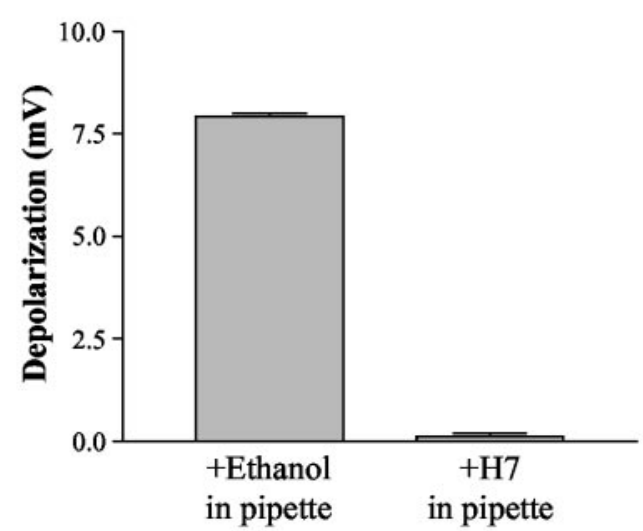

Figure 2. Protein kinases mediate the actions of ORX-A on NTS neurons. A, This NTS neuron was recorded with pipette solution containing 1:1000 ethanol (vehicle control for H7) and depolarized in response to ORX-A $\left(10^{-8} \mathrm{M}\right)$. The depolarization was accompanied by a rapid increase in action potential frequency. After washout of ORX-A, the membrane potential and action potential frequency returned to control levels. Calibration: vertical, $10 \mathrm{mV}$; horizontal, 60 $\mathrm{sec}$. The dashed line indicates baseline membrane potential. $B$, Whole-cell current-clamp recording from an NTS neuron with the nonselective PK inhibitor, $\mathrm{H7}(50 \mu \mathrm{M})$, in pipette solution shows that bath administration of $10^{-8} \mathrm{M}$ ORX-A was without effect. Calibration: vertical, 10 $\mathrm{mV}$; horizontal, $60 \mathrm{sec}$. The dashed line indicates baseline membrane potential. C, This bar graph summarizes the depolarization of NTS neurons caused by $10^{-8} \mathrm{M}$ ORX-A recorded with pipette solution containing 1:1000 ethanol $(7.9 \pm 0.1 \mathrm{mV} ; n=11)$ and $50 \mu \mathrm{M} \mathrm{H7} \mathrm{(0.1 \pm 0.1}$ $\mathrm{mV} ; n=9)$. Error bars indicate SE.

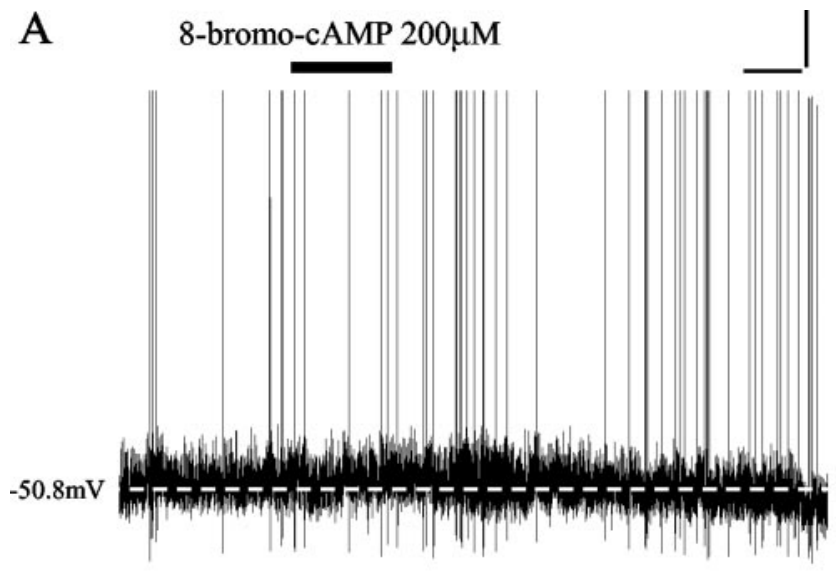

B

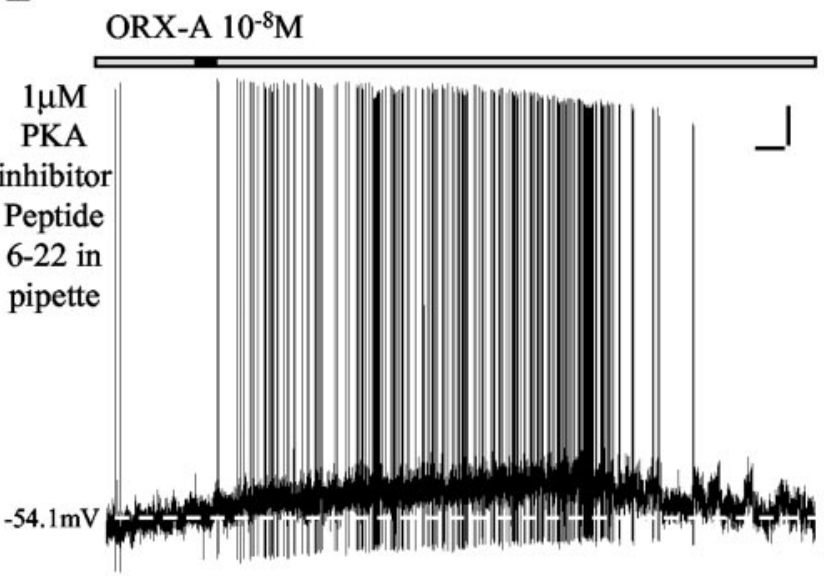

$\mathrm{C}$

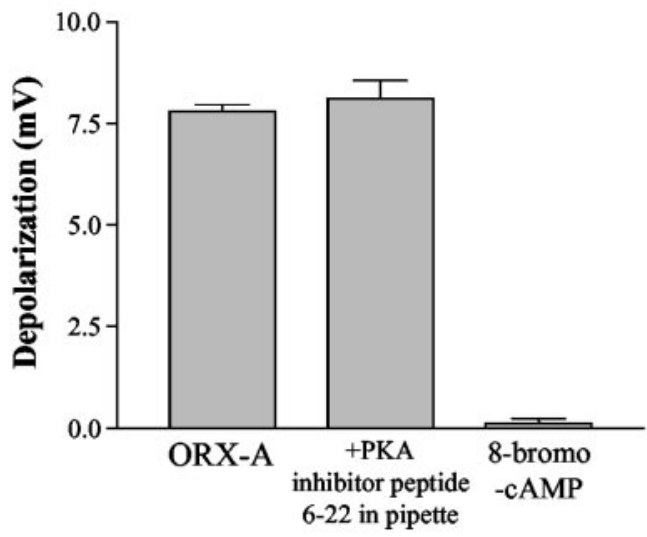

Figure 3. PKA does not mediate the depolarizing effects of ORX-A on NTS neurons. $A$, Bath administration of 8-bromo-cAMP (a cell membrane-permeable, specific PKA agonist) $(200 \mu \mathrm{M})$ did not depolarize NTS neurons as illustrated in this example. Calibration: vertical, $10 \mathrm{mV}$; horizontal, $60 \mathrm{sec}$. The dashed line indicates baseline membrane potential. B, This recording shows an example of the response of an NTS neuron to ORX-A $\left(10^{-8} \mathrm{M}\right)$ with $1 \mu \mathrm{M}$ PKA inhibitor peptide $(6-22)$ in the internal pipette solution, illustrating normal depolarization and increase in spike frequency. After washout of ORX-A, the membrane potential and action potential frequency returned to control levels. Calibration: vertical, $10 \mathrm{mV}$; horizontal, $60 \mathrm{sec}$. The dashed line indicates baseline membrane potential. C, This bar graph illustrates mean depolarization of NTS neurons in response to $10^{-8} \mathrm{M}$ ORX-A $(7.8 \pm 0.2 \mathrm{mV} ; n=55), 200 \mu \mathrm{M}$ 8-bromo-cAMP $(8.1 \pm 0.4 \mathrm{mV} ; n=12)$, and $10^{-8} \mathrm{M}$ ORX-A recorded in the presence of $1 \mu \mathrm{M}$ PKA inhibitor peptide $(6-22)(0.1 \pm 0.1 \mathrm{mV} ; n=6)$. Error bars indicate SE. 
depolarized 12 of 13 NTS neurons (mean depolarization, $8.1 \pm$ $0.4 \mathrm{mV} ; n=12$ of 13 ), the proportion and amplitude of which closely match the data from our previous report (Yang and Ferguson, 2003). These results are consistent with the conclusion that PKA does not mediate the depolarizing actions of ORX-A on NTS neurons.

\section{PKC mediates the depolarizing effects of ORX-A on \\ NTS neurons}

In contrast, aCSF containing $100 \mathrm{nM}$ TPA (a cell membranepermeable, specific PKC agonist) caused long-lasting depolarizations in 7 of 7 NTS neurons tested, as shown in Figure 4, $A$ and $C$. In addition, aCSF containing $100 \mathrm{nM} 4-\alpha$-PMA, the control for TPA, was without effect on NTS cells ( $n=7$ of 7$)$. We next examined the effects of preincubation of medullary slices for $2 \mathrm{hr}$ with $1 \mu \mathrm{M}$ BIS II (a cell membrane-permeable, specific PKC antagonist), which was found to abolish the depolarizing effects of ORX-A on NTS neurons $(n=6$ of 6 ) (Fig. $4 B, C)$. These data are significantly different from the depolarizations caused by ORX-A in aCSF $(7.8 \pm 0.2 \mathrm{mV} ; n=55 ; p<0.0001)$. These data support the conclusion that $\mathrm{PKC}$ production is required for expression of the excitatory effects of ORX-A on NTS neurons.

PKC mediates both the activation of NSCC and inhibition of $I_{\mathrm{K}}$ induced by ORX-A

Our previous voltage-clamp experiments (Yang and Ferguson, 2003) have demonstrated roles for activation of NSCC and inhibition of $I_{\mathrm{K}}$ in mediating the excitatory effects of ORX-A on NTS neurons. We next examined whether PKC inhibition with $1 \mu \mathrm{M}$ BIS II also abolished the effects of ORX-A on these conductances. Medullary slices were again preincubated in aCSF containing 1 $\mu \mathrm{M}$ BIS II for at least $2 \mathrm{hr}$ before NTS cell recordings were obtained.

We first applied slow voltage ramps ( -100 to $0 \mathrm{mV}$ over 10 $\mathrm{sec}$ ) after a $0.5 \mathrm{sec}$ prepulse to $-100 \mathrm{mV}$ (Yang and Ferguson, 2002, 2003) to determine whether the activation of NSCC by ORX-A is mediated by PKC. The average currents from NTS neurons in response to such ramps (each trace is the mean of five ramps) were recorded before and during bath administration of ORX-A $\left(10^{-8} \mathrm{M}\right)$. The difference current (i.e., the theoretical ORX-A-induced current) was obtained by subtracting control ramps from those obtained during ORX-A perfusion. The data presented in Figure $5 A$ show the difference currents in the aCSF (left panel)- and BIS II (right panel)-perfused slices. The mean reversal potential and conductance of the ORX-A-sensitive current measured in aCSF were $-42.4 \pm 2.8 \mathrm{mV}$ and $0.36 \pm 0.02 \mathrm{nS}$ $(n=18)$. In contrast, application of ORX-A did not cause any significant change in this ramp-evoked current in the presence of $1 \mu \mathrm{M}$ BIS II (right panel). Similar effects of $10^{-8} \mathrm{M}$ ORX-A were observed in all six cells tested. The mean difference current for this group of neurons tested (filled squares; $n=6$ ) is shown in Figure $5 B$ together with the equivalent summary data of ORX-A $\left(10^{-8} \mathrm{M}\right.$ )-induced NSCC activation from standard aCSF (open squares; $n=18$ ).

The sustained $\mathrm{K}^{+}$current was then isolated from NTS neurons recorded in $5 \mu \mathrm{M}$ TTX (to block $\mathrm{Na}^{+}$currents) and $5 \mathrm{~mm}$ 4-AP (to block the transient $\mathrm{K}^{+}$current) and was evoked by 20 $\mathrm{mV}$ voltage steps $(0.5 \mathrm{sec})$ from $-100 \mathrm{mV}$ holding potential to $+40 \mathrm{mV}$ (Yang and Ferguson 2003), as shown in the top panels of Figure 6. Exposure to ORX-A $\left(10^{-8} \mathrm{M}\right)$ resulted in statistically significant decreases in the sustained $\mathrm{K}^{+}$current (measured at the end of the pulse) (Fig. $6 \mathrm{~A}$, top panel) in response to the larger depolarizing pulses as indicated by the summary data presented
A

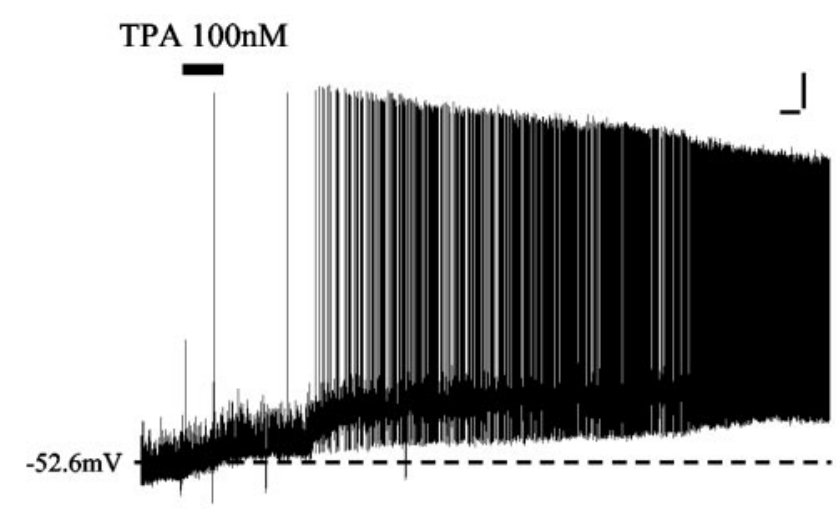

B

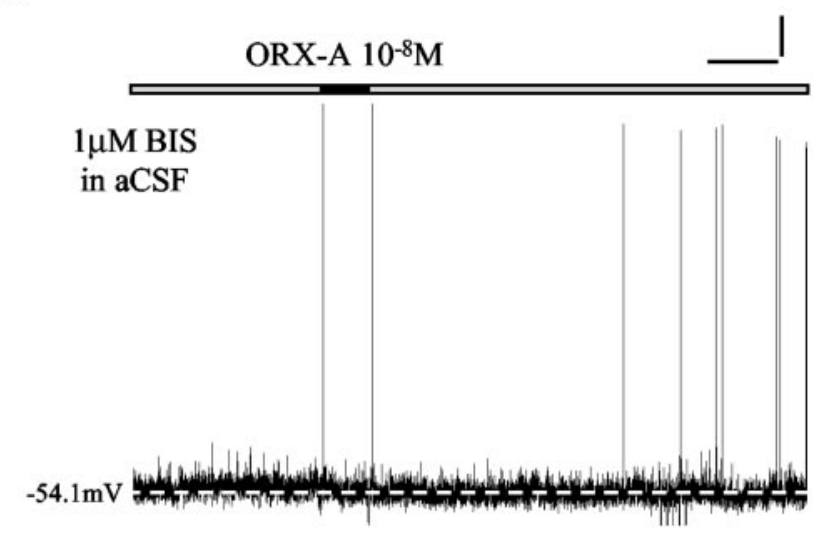

C

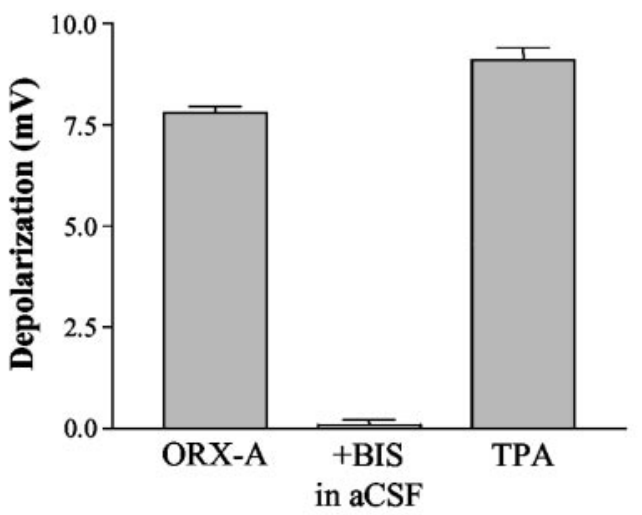

Figure 4. PKC mediates the depolarizing effects of ORX-A on NTS neurons. A, aCSF containing TPA (a cell membrane-permeable, specific PKC agonist) (100 nm) depolarized this NTS neuron in a manner similar to ORX-A. Calibration: vertical, $10 \mathrm{mV}$; horizontal, $60 \mathrm{sec}$. The dashed line indicates baseline membrane potential. $B$, This NTS neuron was recorded in aCSF containing 1 $\mu \mathrm{M}$ BIS II (a cell membrane-permeable, specific PKC antagonist) and, as illustrated, was unaffected by ORX-A. Calibration: vertical, $10 \mathrm{mV}$; horizontal, $60 \mathrm{sec}$. The dashed line indicates baseline membrane potential. C, This bar graph summarizes the depolarization of NTS neurons caused by $10^{-8}{ }_{\mathrm{M}}$ ORX-A $(7.8 \pm 0.2 \mathrm{mV} ; n=55), 10^{-8} \mathrm{M}$ ORX-A with $1 \mu \mathrm{M}$ BIS II in aCSF $(0.1 \pm 0.1 \mathrm{mV} ; n=6)$, and $100 \mathrm{~nm} \mathrm{TPA}(9.1 \pm 0.3 \mathrm{mV} ; n=7)$. Error bars indicate SE.

in the bottom panel of Figure $6 \mathrm{~A}$. After washout of ORX-A and replacement of the bath solution with control aCSF, the sustained $\mathrm{K}^{+}$current returned toward control levels. In the presence of 1 $\mu \mathrm{M}$ BIS II, exposure to ORX-A did not cause any significant 
A
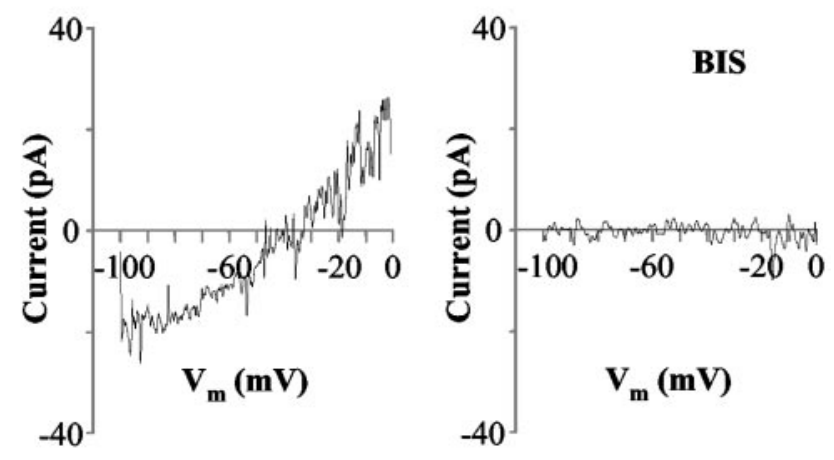

B

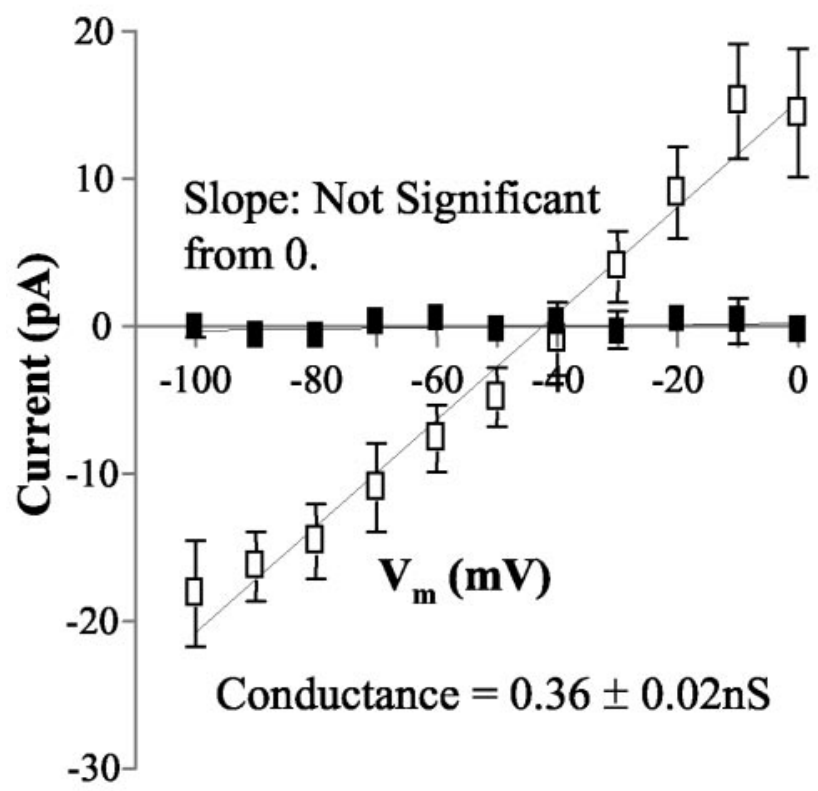

Figure 5. PKC mediates the activation of NSCC induced by ORX-A. A, Mean whole-cell currents evoked by slow depolarizing $(10 \mathrm{mV} / \mathrm{sec})$ voltage ramps were recorded before and during exposure to ORX-A $\left(10^{-8} \mathrm{M}\right)$ in the absence and presence of BIS II $(1 \mu \mathrm{M})$. The difference currents induced by ORX-A $\left(10^{-8} \mathrm{M}\right)$ in the absence (left panel) and presence of BIS II $(1 \mu \mathrm{M})$ (right panel) are shown. $B$, This graph illustrates the mean \pm SEM. ORX-A $\left(10^{-8} \mathrm{M}\right)$ evoked current in the presence (filled squares; $n=6$ ) and absence (open squares; $n=18$ ) of BIS II (1 $\mu \mathrm{M})$. The mean reversal potential and conductance of the ORX-A $\left(10^{-8} \mathrm{M}\right)$-sensitive current in the absence of BIS II are $-42.4 \pm 2.8 \mathrm{mV}$ and $0.36 \pm 0.02 \mathrm{nS}(n=18) . V_{\mathrm{m}}$, Holding membrane potential. Error bars indicate SE.

change in the sustained $\mathrm{K}^{+}$current (measured at the end of the pulse) (Fig. $6 B)(n=6)$.

In summary, these voltage-clamp experiment data demonstrated that BIS II $(1 \mu \mathrm{M})$ blocked the activation of NSCC and inhibition of $I_{\mathrm{K}}$ by ORX-A in NTS neurons. Therefore these results suggested that PKC mediates both the activation of NSCC and the inhibition of $I_{\mathrm{K}}$ induced by ORX-A.

\section{Discussion}

Several lines of evidence have shown that orexins act in the CNS to modulate feeding, sleep-wakefulness, neuroendocrine ho- meostasis, and autonomic regulation (Sakurai et al., 1998; Shirasaka et al., 1999; Sweet et al., 1999; Samson and Resch, 2000; Samson and Taylor, 2001). The distribution of ORX-IR axons as well as ORX receptor mRNA and protein within the NTS, when combined with the well established role of this structure as a critical medullary autonomic control center, suggests that the NTS represents a significant site for potential neuroregulatory actions of ORX. In addition, we recently reported direct effects of ORX-A on the excitability of NTS neurons as a result of modulation of both sustained $\mathrm{K}^{+}$currents and a NSCC (Yang and Ferguson, 2003).

In the present study, we examined the signal transduction pathways mediating these excitatory effects of ORX-A on NTS neurons by combining whole-cell patch-clamp recording from medullary slices with pharmacological manipulation of specific signaling cascades. Recordings with GDP- $\beta-S(0.5 \mathrm{mM})$ in the internal solution confirmed that the effects of ORX-A are, as anticipated, mediated by GPCRs. The excitatory responses to ORX-A also were blocked by a phosphatidylcholine-specific PLC inhibitor, D609 $(10 \mu \mathrm{M})$, observations that indicate direct involvement of PLC in transducing these actions. The involvement of protein kinases as the next step in the signaling cascade resulting in ORX actions was initially confirmed by our demonstration that the nonselective protein kinase inhibitor $\mathrm{H} 7$ also abolished these effects. However, PKA appears not to play a role, because the PKA inhibitor peptide did not block the depolarizing effects of ORX-A on NTS neurons, and bath application of 8-bromocAMP (a PKA agonist) did not mimic the actions of ORX-A. In contrast, aCSF containing TPA (a PKC agonist) elicited both depolarizations and increases in spike frequency that were similar in magnitude (although not reversible) to those observed in response to ORX-A. Furthermore, BIS II (a PKC antagonist) abolished the excitatory actions of ORX-A on NTS neurons. Finally, voltage-clamp experiments demonstrated that BIS II also blocked the ability of ORX-A to activate NSCC and inhibit $I_{\mathrm{K}}$ in NTS neurons, confirming the prerequisite role for PKC in mediating these effects.

Our observations in this study are consistent with previous reports demonstrating that ORX-A elevated $\left[\mathrm{Ca}^{2+}\right]_{i}$ via a PLCPKC-mediated pathway, resulting in increased activity of neurons in arcuate nuclei and ventral tegmental area (Van Den Pol et al., 1998; Uramura et al., 2001). Our results are also in agreement with findings that PKC is involved in ORX-A-stimulated catecholamine secretion from human adrenal cells (Mazzocchi et al., 2001), and that PKC mediates the actions of orexin on ovine somatotropes and nucleus pontis oralis neurons (Chen et al., 2002; Xi et al., 2002). It has been well established that OXRs are coupled to GTP-binding proteins (Sakurai et al., 1998). The G-protein most likely involved in these ORX-A-induced excitatory effects on NTS neurons is $G_{q}$, as implied in other neuronal populations (Van Den Pol et al., 1998; Uramura et al., 2001). Some of these effects such as the $\mathrm{K}^{+}$channel inhibition are typical for $\mathrm{G}_{\mathrm{q}}$-coupled receptors (Wickman and Clapham, 1995; Hamilton et al., 1997; Mark and Herlitze, 2000; Hill and Peralta, 2001). Therefore, our working model is that the stimulation of $\mathrm{G}_{\mathrm{q}}$ by the binding of ORX-A to the orexin receptor(s) on NTS neurons induces the activation of PLC, which triggers the activation of PKC. PKC activation subsequently leads to the enhancement of an NSCC and inhibition of $I_{\mathrm{K}}$ via phosphorylation. The activation of an NSCC and inhibition of $I_{\mathrm{K}}$ then mediate the depolarization and broadening of the action potentials caused by ORX-A in NTS neurons, which may underlie the functional roles 
A

\section{Control ORX-A}

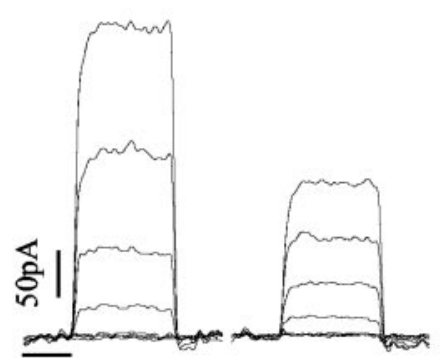

$250 \mathrm{mS}$
B

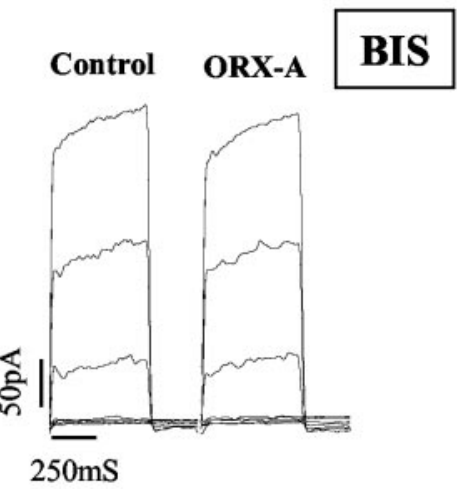

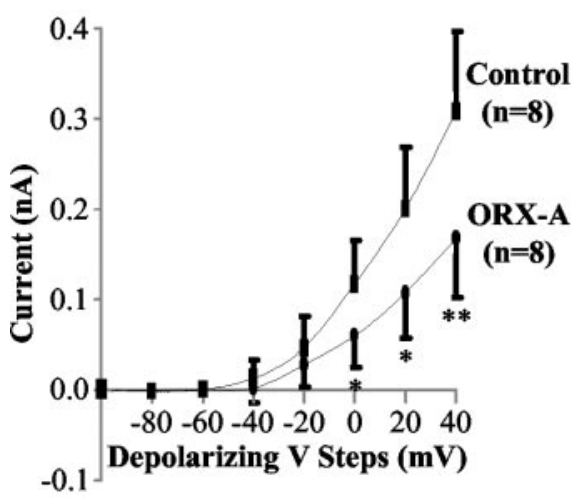

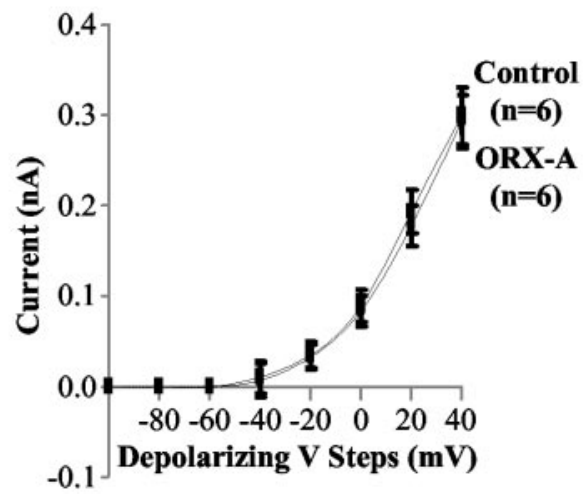

Figure 6. PKC mediates the inhibition of $I_{K}$ induced by ORX-A. A, Top panel, The sustained $\mathrm{K}^{+}$current (measured at the end of the pulse) evoked by voltage steps ( $0.5 \mathrm{sec}$ ) in $20 \mathrm{mV}$ increments from a holding potential of -100 to $+40 \mathrm{mV}$ was pharmacologically isolated in this NTS neuron (with $5 \mu \mathrm{m}$ TTX and $5 \mathrm{~mm} 4$ 4-AP in aCSF). Two panels show the sustained $\mathrm{K}^{+}$current before (left) and during (right) ORX-A $\left(10^{-8} \mathrm{M}\right)$ exposure. Calibration: vertical, $50 \mathrm{pA}$; horizontal, $250 \mathrm{sec}$. Bottom panel, Summary data of the sustained $\mathrm{K}^{+}$current (measured at the end of the pulse) recorded before (squares) and during (circles) extracellular application of $10^{-8}{ }_{\mathrm{M}}$ ORX-A $(n=8)$ demonstrate that the sustained $\mathrm{K}^{+}$current was decreased by exposure to ORX-A. $B$, Top panel, In the presence of BIS II (1 $\mu \mathrm{M})$, exposure to ORX-A $\left(10^{-8} \mathrm{M}\right)$ did not cause any significant change in the sustained $\mathrm{K}^{+}$ current (measured at the end of the pulse). Bottom panel, Summary data of the sustained $\mathrm{K}^{+}$current (measured at the end of the pulse) recorded before (squares) and during (circles) extracellular application of $10^{-8} \mathrm{M} O \mathrm{RX}-\mathrm{A}(n=6)$ in the presence of BIS II demonstrate that the sustained $\mathrm{K}^{+}$current was unaffected by exposure to ORX-A. ${ }^{*} p<0.05,{ }^{* *} p<0.01$ compared with control values. Error bars indicate $\mathrm{SE}$.

of orexin in the central autonomic control at the NTS as suggested by our previous study (Smith et al., 2002).

In conclusion, this study provides evidence that the excitatory effects of ORX-A on NTS neurons are mediated through activation of the PLC-PKC-NSCC and $-I_{\mathrm{K}}$ signaling cascades, which probably result from OXR-coupled activation of $\mathrm{G}_{\mathrm{q}}$-protein. Understanding the cellular mechanisms of action of the ORXs in the NTS is an important step in gaining insight into the physiologic role of ORX in the CNS regulation of a variety of homeostatic events triggered by activation of NTS neurons.

\section{References}

Chen C, Xu RW, Ueta Y, Kilduff TS (2002) Orexin-A augments L-type $\mathrm{Ca}^{2+}$ current and GHRH-induced GH secretion in ovine somatotropes in vitro. Soc Neurosci Abstr 28:175.11.

Cluderay JE, Harrison DC, Hervieu GJ (2002) Protein distribution of the orexin-2 receptor in the rat central nervous system. Regul Pept 104:131-144.

Date Y, Ueta Y, Yamashita H, Yamaguchi H, Matsukura S, Kangawa K, Sakurai T, Yanagisawa M, Nakazato M (1999) Orexins, orexigenic hypothalamic peptides, interact with autonomic, neuroendocrine and neuroregulatory systems. Proc Natl Acad Sci USA 96:748-753.

de Lecea L, Kilduff TS, Peyron C, Gao X, Foye PE, Danielson PE, Fukuhara C, Battenberg EL, Gautvik VT, Bartlett FS, Frankel WN, Van Den Pol AN, Bloom FE, Gautvik KM, Sutcliffe JG (1998) The hypocretins: hypothalamus-specific peptides with neuroexcitatory activity. Proc Natl Acad Sci USA 95:322-327.

Eriksson KS, Sergeeva O, Brown RE, Haas HL (2001) Orexin/hypocretin excites the histaminergic neurons of the tuberomammillary nucleus. J Neurosci 21:9273-9279.

Exton JH (1994) Phosphatidylcholine breakdown and signal transduction. Biochim Biophys Acta 1212:26-42.

Fischer SM, Patrick KE, Lee ML, Cameron GS (1991) $4 \beta$-and $4 \alpha$-12-O-tetradecanoylphorbol13 -acetate elicit arachidonate release from epidermal cells through different mechanisms. Cancer Res 51:850-856.

Glass DB, Cheng HC, Mende-Mueller L, Reed J, Walsh DA (1989) Primary structural determinants essential for potent inhibition of cAMP-dependent protein kinase by inhibitory peptides corresponding to the active portion of the heat-stable inhibitor protein. J Biol Chem 264:8802-8810.

Hamilton SE, Loose MD, Qi M, Levey AI, Hille B, McKnight GS, Idzerda RL, Nathanson NM (1997) Disruption of the $\mathrm{m} 1$ receptor gene ablates muscarinic receptor-dependent $\mathrm{M}$ current regulation and seizure activity in mice. Proc Natl Acad Sci USA 94:13311-13316.

Hei YJ, MacDonell KL, McNeill JH, Diamond J (1991) Lack of correlation between activation of cyclic AMP-dependent protein kinase and inhibition of contraction of rat vas deferens by cyclic AMP analogs. Mol Pharmacol 39: 233-238.

Hervieu GJ, Cluderay JE, Harrison DC, Roberts JC, Leslie RA (2001) Gene expression and protein distribution of the orexin-1 receptor in the rat brain and spinal cord. Neuroscience 103:777-797.

Hill JJ, Peralta EG (2001) Inhibition of a $\mathrm{G}_{\mathrm{i}}$ activated potassium channel (GIRK1/4) by the $\mathrm{G}_{\mathrm{q}}$-coupled $\mathrm{m} 1$ muscarinic acetylcholine receptor. J Biol Chem 276:5505-5510.

Ho RJ, Shi QH, Ruiz J (1986) Conditional inhibition of forskolin-activated adenylate cyclase by guanosine diphosphate and its analog. Arch Biochem Biophys 251:148-155.

Horvath TL, Peyron C, Diano S, Ivanov A, Aston-Jones G, Kilduff TS, Van Den Pol AN (1999) Hypocretin (orexin) activation and synaptic innervation of the locus coeruleus noradrenergic system. J Comp Neurol 415:145-159.

Lawrence AJ, Jarrott B (1996) Neurochemical modulation of cardiovascular control in the nucleus tractus solitarius. Prog Neurobiol 48:21-53.

LiZ, Ferguson AV (1996) Electrophysiological properties of paraventricular magnocellular neurons in rat brain slices: modulation of $I_{\mathrm{A}}$ by angiotensin II. Neuroscience 71:133-145.

Lu XY, Bagnol D, Burke S, Akil H, Watson SJ (2000) Differential distribution and regulation of $\mathrm{OX}_{1}$ and $\mathrm{OX}_{2}$ orexin/hypocretin receptor messenger RNA in the brain upon fasting. Horm Behav 37:335-344.

Marcus JN, Aschkenasi CJ, Lee CE, Chemelli RM, Saper CB, Yanagisawa M, Elmquist JK (2001) Differential expression of orexin receptors 1 and 2 in the rat brain. J Comp Neurol 435:6-25.

Mark MD, Herlitze S (2000) G-protein mediated gating of inward-rectifier $\mathrm{K}^{+}$channels. Eur J Biochem 267:5830-5836.

Mazzocchi G, Malendowicz LK, Aragona F, Rebuffat P, Gottardo L, Nussdorfer GG (2001) Human pheochromocytomas express orexin receptor type 2 gene and display an in vitro secretory response to orexins A and B. J Clin Endocrinol Metab 86:4818-4821.

Peyron C, Tighe DK, Van Den Pol AN, de Lecea L, Heller HC, Sutcliffe JG, Kilduff TS (1998) Neurons containing hypocretin (orexin) project to multiple neuronal systems. J Neurosci 18:9996-10015.

Quick J, Ware JA, Driedger PE (1992) The structure and biological activities 
of the widely used protein kinase inhibitor, $\mathrm{H}_{7}$, differ depending on the commercial source. Biochem Biophys Res Commun 187:657-663.

Rebois RV, Patel J (1985) Phorbol ester causes desensitization of gonadotropin-responsive adenylate cyclase in a murine Leydig tumor cell line. J Biol Chem 260:8026-8031.

Sakurai T, Amemiya A, Ishii M, Matsuzaki I, Chemelli RM, Tanaka H, Williams SC, Richardson JA, Kozlowski GP, Wilson S, Arch JR, Buckingham RE, Haynes AC, Carr SA, Annan RS, McNulty DE, Liu WS, Terrett JA, Elshourbagy NA, Bergsma DJ, et al. (1998) Orexins and orexin receptors: a family of hypothalamic neuropeptides and G protein-coupled receptors that regulate feeding behavior. Cell 92:573-585.

Samson W, Resch ZT (2000) The hypocretin/orexin story. Trends Endocrinol Metab 11:257-262.

Samson WK, Taylor MM (2001) Hypocretin/orexin suppresses corticotroph responsiveness in vitro. Am J Physiol 281:R1140-R1145.

Shirasaka T, Nakazato M, Matsukura S, Takasaki M, Kannan H (1999) Sympathetic and cardiovascular actions of orexins in conscious rats. Am J Physiol 277:R1780-R1785.

Smith PM, Connolly BC, Ferguson AV (2002) Microinjection of orexin into the rat nucleus tractus solitarius causes increases in blood pressure. Brain Res 950:261-267.

Sweet DC, Levine AS, Billington CJ, Kotz CM (1999) Feeding response to central orexins. Brain Res 821:535-538.

Toullec D, Pianetti P, Coste H, Bellevergue P, Grand-Perret T, Ajakane M, Baudet V, Boissin P, Boursier E, Loriolle F (1991) The bisindolylmaleimide GF $109203 \mathrm{X}$ is a potent and selective inhibitor of protein kinase C. J Biol Chem 266:15771-15781.

Trivedi P, Yu H, MacNeil DJ, Van der Ploeg LH, Guan XM (1998) Distribution of orexin receptor mRNA in the rat brain. FEBS Lett 438:71-75.
Uramura K, Funahashi H, Muroya S, Shioda S, Takigawa M, Yada T (2001) Orexin-A activates phospholipase $\mathrm{C}$ - and protein kinase $\mathrm{C}$-mediated $\mathrm{Ca}^{2+}$ signaling in dopamine neurons of the ventral tegmental area. NeuroReport 12:1885-1889.

Van Den Pol AN (1999) Hypothalamic hypocretin (orexin): robust innervation of the spinal cord. J Neurosci 19:3171-3182.

Van Den Pol AN, Gao XB, Obrietan K, Kilduff TS, Belousov AB (1998) Presynaptic and postsynaptic actions and modulation of neuroendocrine neurons by a new hypothalamic peptide, hypocretin/orexin. J Neurosci 18:7962-7971.

Van Den Pol AN, Patrylo PR, Ghosh PK, Gao XB (2001) Lateral hypothalamus: early developmental expression and response to hypocretin (orexin). J Comp Neurol 433:349-363.

Vincent A, Tell F (1997) Postnatal changes in electrophysiological properties of rat nucleus tractus solitarii neurons. Eur J Neurosci 9:1612-1624.

Wickman K, Clapham DE (1995) Ion channel regulation by G proteins. Physiol Rev 75:865-885.

Xi MC, Lopez-Rodriguez F, Morales FR, Chase MH (2002) Hypocretininduced active (REM) sleep is mediated by G-protein activation of protein kinase C (PKC). Soc Neurosci Abstr 28:776.10.

Yang B, Ferguson AV (2002) Orexin-A depolarizes dissociated rat area postrema neurons through activation of a nonselective cationic conductance. J Neurosci 22:6303-6308.

Yang B, Ferguson AV (2003) Orexin-A depolarizes nucleus tractus solitarius neurons through effects on non-selective cationic and $\mathrm{K}^{+}$conductances. J Neurophysiol 89:2167-2175.

Yates BJ, Grelot L, Kerman IA, Balaban CD, Jakus J, Miller AD (1994) Organization of vestibular inputs to nucleus tractus solitarius and adjacent structures in cat brain stem. Am J Physiol 267:R974-R983. 